\title{
Annual and Lunar Periodicity in the Sexual Cycle of the Javanese Toad, Bufo melanostictus Schneider ${ }^{1}$
}

\author{
GiLbert Church \\ University of California Field Staff, \\ Medical Faculty, University of Indonesia, Djakarta ${ }^{2}$
}

(Plate I; Text-figures $1 \& 2$ )

$\mathrm{T}$ he reproductive cycles of the temperate zone Anura have been known for many years to correspond closely to seasonal changes in climate. Almost nothing, however, is known about the reproductive cycles of tropical amphibians. In the wet tropics the average temperature is almost constantly the same and the amount of rainfall, although usually undergoing seasonal variations, is never so slight as to cause drought conditions. Consequently, a constant supply of food is available. The breeding cycles of Amphibia in such an unchanging environment might be expected to differ significantly from those of the variable temperate zones.

This report presents a study of the reproductive cycle of Bufo melanostictus Schneider in a truly tropical environment. The city of Djakarta, at the western end of the island of Java, where the animals were collected, lies about $6^{\circ} \mathrm{S}$. Being so close to the equator, the days are about twelye hours long throughout the year.

The climate of Djakarta is constantly warm and humid. The average monthly temperature throughout the year varies from about $26^{\circ} \mathrm{C}$. to $28^{\circ} \mathrm{C}$.; the absolute maximum and minimum temperature range is from $18^{\circ} \mathrm{C}$. to $36^{\circ} \mathrm{C}$. The mean monthly relative humidity varies between $78 \%$ and $88 \%$.

Of all conditions in Djakarta, the amount of rainfall varies most throughout the year, the

1 This study was supported by a grant from the Gustav and Louise Pfeiffer Research Foundation of New York City, and the China Medical Board.

2 Present address: Departemen Kimia/Biologi, Institut Teknologi, Djl. Ganeça 10, Bandung, Indonesia. changes producing so-called "wet" and "dry" seasons. The rainfall is greatest from December to March during the northwest monsoon, and in January averages about 8". From April to October the southeast monsoon brings less rain, but local thunderstorms, occurring on the average of 122 per year, are common. The average rainfall for the month of September is about 2".

In this monotonously damp climate B. melanostictus occurs widely and in large numbers. It is an urban, nocturnal toad, most frequently found around human habitation. In the evening it is often aggressive enough to invade houses and porches in its hunt for insects, and it will often congregate under street lamps in quiet areas for the same purpose. It breeds in drainage ditches or other shallow standing water, and the eggs are laid in typical Bufo fashion in two mucilaginous strings during amplexus which may continue for one or two days before actual spawning takes place. (Church, 1960).

The females for this study were collected at weekly intervals from September, 1957, to September, 1958; the males, from March to July, and September to November, 1958. Studies of the blood, hormonal changes and the concentration of liver glycogen as related to the sexual cycle of this species throughout the same period have also been made but will be presented later.

A preliminary report of this work was presented at the First Indonesian Science Congress at Malang (Java) in August, 1958 (Church et al, 1958).

\section{Materials and Methods}

1. Female specimens. For this study between ten and twenty adult female specimens were collected one evening each week in Menteng, a dis- 
trict of Djakarta. The following morning they were brought to the laboratory, killed and examined. Records were kept of the snout-vent lengths, total body weights, weights of the ovaries, the maturity of the ovarian eggs, the presence of ovulated eggs, the size of the oviducts, the amount of food in the stomach and the presence or absence of fat bodies.

The ovaries were excised and weighed separately until it became apparent that there was no significant difference between the weights of the two. The maturity of the ovarian eggs was determined by a consideration of egg size and pigmentation. They were grouped as follows:

Group I: Small, unpigmented ova.

Group II: Eggs small; pigmentation of ova variable.

Group III: Almost all eggs pigmented completely, but showing no distinction between the animal and vegetal hemispheres.

Group IV: A difference in pigmentation beginning to appear between the animal and vegetal hemispheres.

Group V: Large eggs with a clearly distinguishable animal and vegetal hemisphere.

Group VI: Post-ovulation, distinguished by the condition of the ovary, which usually contained some unovulated Group V ova.

2. Male specimens. The testes of a smaller number of animals, collected also at weekly intervals from the same area as the females, were studied. Approximately seven male toads were examined every week from March to July, 1958. In a total of 130 animals, records were kept of the snout-vent lengths, and the total body weights. The lengths and the widths of the testes were determined, and the weights recorded. One of the testes of each male was crushed in water and examined for viable spermatozoa. Records were also kept of the pigmentation of the fingers, the presence of Bidder's organ, and the number of vocal slits leading to the vocal sac.

A histological study of the testes was made on another group of 200 males which were collected at weekly intervals from September to November, 1958. To determine whether only mating animals with testes full of sperm were to be found in water, half the animals were taken from land and half from water. The testes were excised the morning after the animals were collected, fixed in Bouin's, sectioned at $8 \mathrm{mu}$, and stained with Mallory's phosphotungstic hematoxylin. Records were also kept of the snout-vent lengths, the gross body weights and the secondary sex characters of these animals.

\section{RESUlts}

1. Female specimens. A total of 878 females were studied. The average snout-vent length was $70 \mathrm{~mm}$.; the average gross weight, 32.9 gms. The weekly data collected over the whole year are presented in Table I.

It was found that the ovarian weights varied considerably throughout the year. They were largest from September to November, decreased markedly in January and February, and reached their smallest size in March and April (Text-fig. 1). Considerable evidence was accumulated from December to March to indicate that in many cases not all eggs were ovulated at the same time but, presumably, in two or even three small batches over a number of months. Animals kept in the laboratory were found to undergo the same spawning variations and some females were even able to ovulate without the presence of a male. Ovaries examined eight months after females had spawned in the laboratory contained eggs which had reached Group III in development.

A fully developed pair of ovaries containing ova ready to be ovulated could equal as much as $30 \%$ of the gross body weight. On the other hand, a Group I immature ovary sometimes weighed as little as $0.3 \mathrm{gm}$. Ova in three stages of development could be found in the ovary: the youngest generation was small, clear and transparent; the second, medium in size and yellow in color; and the most mature, large and pigmented. After ovulation of the mature ova the remaining two generations continued to develop and a new generation was produced. A similar condition has been reported in B. arenarum (Allende, 1939).

Within the yearly variation in the weights of the ovaries, there was also found to exist a monthly rhythm in ovulation which followed the lunar cycle. During the time of the full moon more females were collected that were ready to ovulate or had just ovulated than when there was no moon. Attempts to correlate this cycle with temperature changes and amounts of rainfall have been unsuccessful. These data are presented graphically in Text-fig. 2.

The size of the oviducts could invariably be correlated with the maturity of the ovaries. If the ovarian eggs were immature, the oviducts were almost threadlike. When the ovaries contained mature eggs, the oviducts were large and swollen and greatly convoluted.

The stomach contents were not weighed, but food was invariably present in the stomach throughout the time studied.

Occasional animals were found with large fat 
Table I. Weekly Averages of Data for Female SPECIMENS OF $B$. melanostictus EXAMINED FROM SePtember, 1957, to August, 1958.

\begin{tabular}{|c|c|c|c|c|c|c|}
\hline Date & No. & 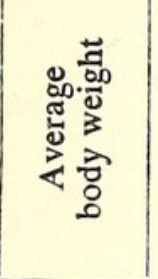 & 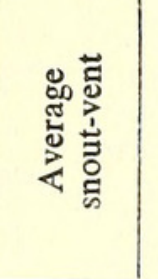 & 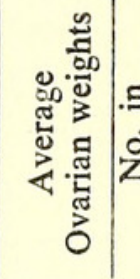 & 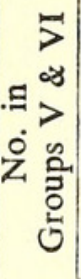 & 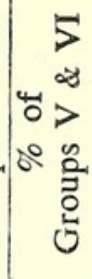 \\
\hline $\begin{array}{r}\text { Sept. } 11 \\
18 \\
25\end{array}$ & $\begin{array}{l}17 \\
13 \\
15\end{array}$ & $\begin{array}{l}49.2 \mathrm{gm} . \\
34.9 \\
47.1\end{array}$ & $\begin{array}{l}79.6 \mathrm{~mm} . \\
68.3 \\
76.0\end{array}$ & $\begin{array}{l}4.1 \mathrm{gm} \text {. } \\
2.8 \\
5.3\end{array}$ & n. $\begin{array}{l}1 \\
2 \\
0\end{array}$ & $\begin{array}{l}6 \% \\
15 \\
0\end{array}$ \\
\hline $\begin{array}{r}\text { Oct. } 2 \\
9 \\
17 \\
23 \\
30\end{array}$ & $\begin{array}{l}10 \\
17 \\
20 \\
19 \\
13\end{array}$ & $\begin{array}{l}56.6 \\
31.9 \\
36.9 \\
46.5 \\
40.7\end{array}$ & $\begin{array}{l}82.8 \\
68.1 \\
69.9 \\
73.8 \\
66.9\end{array}$ & $\begin{array}{l}8.1 \\
2.7 \\
4.1 \\
7.6 \\
7.5\end{array}$ & $\begin{array}{l}0 \\
1 \\
2 \\
4 \\
1\end{array}$ & $\begin{array}{r}0 \\
6 \\
10 \\
21 \\
7\end{array}$ \\
\hline $\begin{array}{r}\text { Nov. } 6 \\
13 \\
20 \\
27\end{array}$ & $\begin{array}{r}19 \\
6 \\
13 \\
18\end{array}$ & $\begin{array}{l}45.2 \\
33.6 \\
35.3 \\
39.4\end{array}$ & $\begin{array}{l}75.4 \\
75.3 \\
72.3 \\
76.7\end{array}$ & $\begin{array}{r}11.4 \\
6.2 \\
5.8 \\
6.5\end{array}$ & $\begin{array}{l}7 \\
2 \\
4 \\
3\end{array}$ & $\begin{array}{l}36 \\
33 \\
30 \\
17\end{array}$ \\
\hline $\begin{array}{r}4 \\
11 \\
18 \\
24 \\
31\end{array}$ & $\begin{array}{l}22 \\
16 \\
16 \\
19 \\
17\end{array}$ & $\begin{array}{l}34.0 \\
29.4 \\
35.4 \\
32.1 \\
23.9\end{array}$ & $\begin{array}{l}74.1 \\
66.7 \\
75.3 \\
73.3 \\
67.6\end{array}$ & $\begin{array}{l}4.0 \\
3.0 \\
6.3 \\
3.2 \\
3.2\end{array}$ & $\begin{array}{r}14 \\
8 \\
1 \\
2 \\
0\end{array}$ & $\begin{array}{r}63 \\
50 \\
6 \\
10 \\
0\end{array}$ \\
\hline $\begin{array}{r}\text { Jan. } 7 \\
15 \\
22 \\
29\end{array}$ & $\begin{array}{l}19 \\
18 \\
18 \\
20\end{array}$ & $\begin{array}{l}37.3 \\
29.7 \\
37.2 \\
30.7\end{array}$ & $\begin{array}{l}73.7 \\
75.0 \\
76.0 \\
71.5\end{array}$ & $\begin{array}{l}4.8 \\
1.8 \\
5.1 \\
4.7\end{array}$ & $\begin{array}{r}8 \\
12 \\
2 \\
3\end{array}$ & $\begin{array}{l}42 \\
75 \\
11 \\
15\end{array}$ \\
\hline Feb. $\begin{array}{r}5 \\
12 \\
19 \\
26\end{array}$ & $\begin{array}{l}10 \\
11 \\
12 \\
17\end{array}$ & $\begin{array}{l}38.1 \\
28.5 \\
23.3 \\
24.5\end{array}$ & $\begin{array}{l}77.1 \\
75.4 \\
67.3 \\
69.7\end{array}$ & $\begin{array}{l}3.9 \\
2.6 \\
1.4 \\
1.2\end{array}$ & $\begin{array}{l}3 \\
2 \\
0 \\
2\end{array}$ & $\begin{array}{r}34 \\
18 \\
0 \\
11\end{array}$ \\
\hline $\begin{array}{r}\text { Mar. } 5 \\
12 \\
19 \\
26\end{array}$ & $\begin{array}{l}21 \\
12 \\
10 \\
16\end{array}$ & $\begin{array}{l}29.3 \\
29.8 \\
32.5 \\
25.1\end{array}$ & $\begin{array}{l}71.7 \\
74.0 \\
76.7 \\
70.3\end{array}$ & $\begin{array}{l}2.6 \\
1.6 \\
3.1 \\
1.4\end{array}$ & $\begin{array}{l}5 \\
3 \\
2 \\
3\end{array}$ & $\begin{array}{l}25 \\
25 \\
20 \\
33\end{array}$ \\
\hline $\begin{array}{r}\text { Apr. } 2 \\
10 \\
16 \\
23 \\
30\end{array}$ & $\begin{array}{l}16 \\
13 \\
16 \\
14 \\
24\end{array}$ & $\begin{array}{l}23.9 \\
32.3 \\
20.9 \\
26.5 \\
23.0\end{array}$ & $\begin{array}{l}67.4 \\
65.7 \\
64.2 \\
68.6 \\
68.8\end{array}$ & $\begin{array}{l}1.1 \\
1.7 \\
2.6 \\
1.5 \\
1.3\end{array}$ & $\begin{array}{l}1 \\
0 \\
0 \\
1 \\
1\end{array}$ & $\begin{array}{l}6 \\
0 \\
0 \\
7 \\
4\end{array}$ \\
\hline $\begin{array}{r}7 \\
14 \\
21 \\
28\end{array}$ & $\begin{array}{l}21 \\
20 \\
24 \\
21\end{array}$ & $\begin{array}{l}28.8 \\
35.5 \\
31.9 \\
34.5\end{array}$ & $\begin{array}{l}71.8 \\
66.4 \\
73.3 \\
79.7\end{array}$ & $\begin{array}{l}1.4 \\
1.7 \\
1.5 \\
2.4\end{array}$ & $\begin{array}{l}3 \\
1 \\
0 \\
1\end{array}$ & $\begin{array}{r}14 \\
5 \\
0 \\
5\end{array}$ \\
\hline $\begin{array}{r}\text { June } 4 \\
11 \\
18 \\
25\end{array}$ & $\begin{array}{l}25 \\
28 \\
11 \\
17\end{array}$ & $\begin{array}{l}23.6 \\
33.9 \\
30.5 \\
29.4\end{array}$ & $\begin{array}{l}69.2 \\
69.1 \\
68.7 \\
71.0\end{array}$ & $\begin{array}{l}1.0 \\
3.0 \\
2.6 \\
1.6\end{array}$ & $\begin{array}{l}3 \\
1 \\
1 \\
4\end{array}$ & $\begin{array}{r}12 \\
3 \\
5 \\
16\end{array}$ \\
\hline $\begin{array}{r}\text { July } \\
2 \\
9 \\
16 \\
23\end{array}$ & $\begin{array}{l}24 \\
20 \\
19 \\
24\end{array}$ & $\begin{array}{l}32.1 \\
39.9 \\
24.2 \\
33.5\end{array}$ & $\begin{array}{l}72.1 \\
73.7 \\
64.0 \\
65.6\end{array}$ & $\begin{array}{l}2.6 \\
2.6 \\
0.8 \\
1.6\end{array}$ & $\begin{array}{l}7 \\
6 \\
0 \\
6\end{array}$ & $\begin{array}{r}29 \\
30 \\
0 \\
25\end{array}$ \\
\hline $\begin{array}{r}\text { Aug. } 6 \\
13 \\
20 \\
27\end{array}$ & $\begin{array}{l}24 \\
23 \\
21 \\
19\end{array}$ & $\begin{array}{l}29.4 \\
26.6 \\
30.9 \\
34.3\end{array}$ & $\begin{array}{l}66.5 \\
62.6 \\
65.7 \\
68.5\end{array}$ & $\begin{array}{l}1.1 \\
1.5 \\
1.6 \\
3.6\end{array}$ & $\begin{array}{l}1 \\
5 \\
6 \\
6\end{array}$ & $\begin{array}{r}4 \\
21 \\
28 \\
31\end{array}$ \\
\hline
\end{tabular}

bodies, but in the majority of cases these organs were rarely of a size to store any appreciable amount of fat. Usually the fat bodies were entirely lacking, or almost invisible. The constancy of the climate and the unending food supply obviously make an estivation period unnecessary; consequently, the storage of fat either for the maintenance of general metabolism or the production of ova becomes superfluous. There was no correlation between the size or presence of fat bodies and the maturity of the ovarian eggs, and no explanation can be given for the presence of large fat bodies in those few cases in which they were found. Neither the presence nor the size of the fat bodies varied throughout the year as has been reported to be the case for this species in Thailand (Alexander, 1933).

2. Male specimens. Two groups of males were studied. In the first group totalling 130 animals, approximately seven male toads were examined weekly from March until July, 1958. In the second, totalling 200 animals, the testes of approximately twenty animals were examined histologically every week during the months of September and October, 1958.

The testes of $B$. melanostictus are elongated and in mature animals are typically grayishyellow; those of young males are opaque white. In about $20 \%$ of the animals examined either one or both testes were divided into two or three separate lobules which were sometimes connected together.

The average weight of a mature testis, taken as percentage of the body weight, was $0.1 \%$. The average length of the testis was $11.2 \mathrm{~mm}$.; the average diameter, $2.4 \mathrm{~mm}$. There was no significant difference between the weights, lengths or diameters of the right and left testes. These data, including the snout-vent lengths and gross body weights, for each week, are tabulated in Table II.

There was no obvious correlation between the condition of the testes and the monthly ovarian cycle. Changes in the weights and volumes of the testes which occurred from week to week were probably related to changes in snout-vent size.

All of the testes which were crushed were found to contain some viable mature spermatozoa. Histological sections also showed this to be so, although in about $18 \%$ of the testes examined microscopically the tubules had been evacuated. Another $27 \%$ had evacuted some but not all of the mature spermatozoa; $19 \%$ had tubules full of mature sperm ready to evacuate; $20 \%$ had tubules in which the developing and mature sperm were present in about equal numbers; and $15 \%$ were in the early stages of 


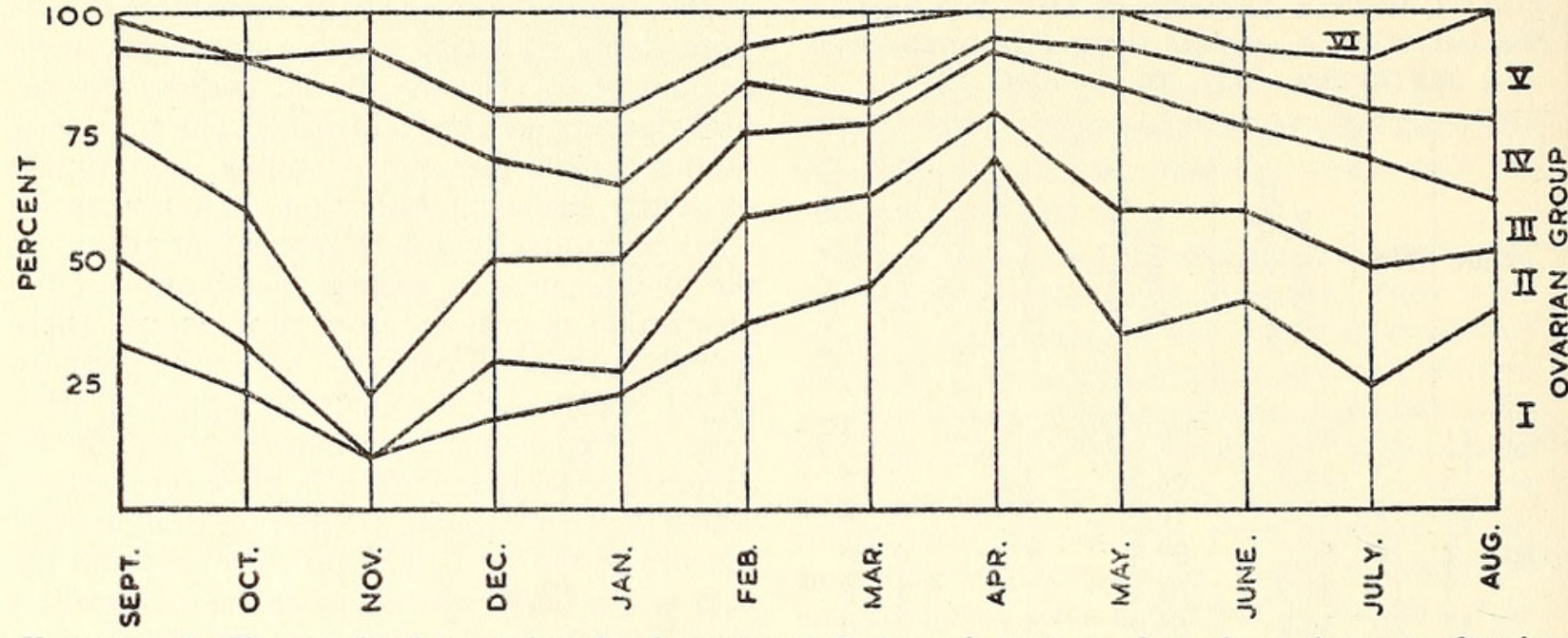

TeXT-Fig. 1. Changes in the ovarian development of Bufo melanostictus throughout the year. Ovarian Group I represents the most immature ovaries; Group V and VI, ovaries containing eggs ready to be ovulated or post-ovulation. Animals with Group I ovaries were most numerous in April; those in Groups $\mathrm{V}$ and VI, during December and January.

spermatozoa development, although even here it was sometimes possible to find a tubule containing mature sperm.

The testes did not show seasonal lobulation, but every tubule formed an active center of spermatogenesis. A recently evaculated tubule might lack mature spermatozoa, but at least three stages of development (primary spermatocytes, spermatogonia and spermatids) could be found in every tubule. The developing spermatogonia and spermatids of the tubules were arranged in groups separated in a mature tubule by Sertoli cells holding spermatozoa
(Plate I, A). In the testis of an animal apparently ready to mate, the spermatozoa had become disengaged from the Sertoli cells and were found freely filling the tubular lumina (Plate I, B).

There was no clear-cut distinction between the thickness or the amount of interstitial tissue present in the different stages of development of the tubules. In the few instances in which the interstitial tissue was obviously thicker, the tubules had just been evacuated, and this apparent increase may have been due to stretching of the interstitial tissue caused by the collapsed tubule (Plate I, C).

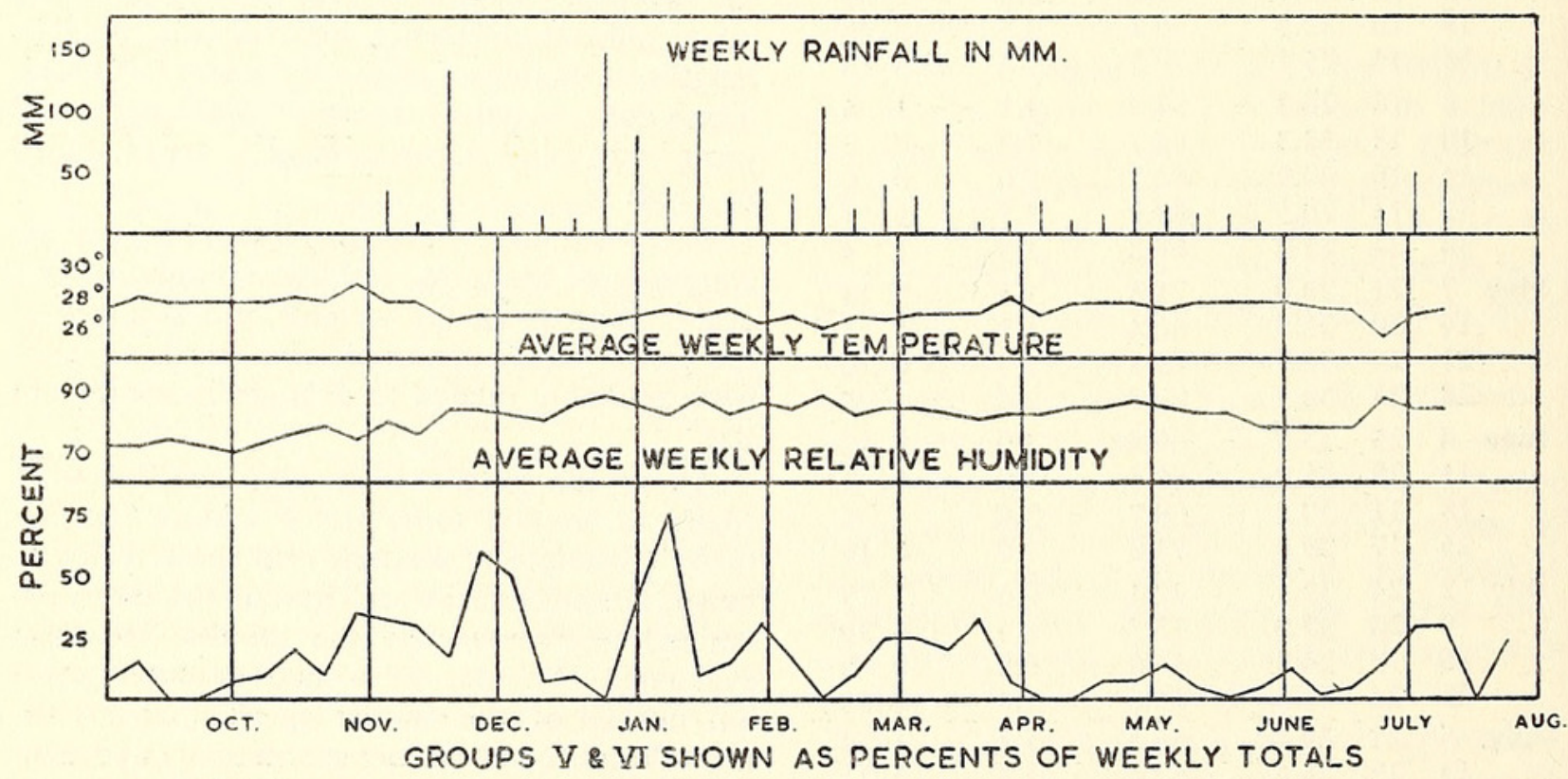

TexT-FIG. 2. Weekly percentages of animals in Groups V and VI from September, 1957, to August, 1958. Vertical lines mark approximate days of full moon. Data on rainfall, temperature and humidity supplied by Lembaga Meteorologi dan Geofisik, Kementerian Perhubungan, Djakarta. 
Table II. Weekly Averages of Data for Male Specimens of B. melanostictus Examined from March-July, 1958.

\begin{tabular}{|c|c|c|c|c|c|c|c|c|c|c|c|c|}
\hline & & \multirow{3}{*}{ No. } & \multirow{3}{*}{$\begin{array}{l}\mathrm{S}-\mathrm{V} \\
\mathrm{mm} .\end{array}$} & \multirow{3}{*}{$\begin{array}{l}\text { Body } \\
\text { wt. } \\
\text { gms. }\end{array}$} & \multicolumn{8}{|c|}{ Left and Right Testes } \\
\hline & & & & & \multicolumn{2}{|c|}{$\begin{array}{l}\text { Weight } \\
\text { mgms. }\end{array}$} & \multicolumn{2}{|c|}{$\begin{array}{l}\text { Length } \\
\mathrm{mm} .\end{array}$} & \multicolumn{2}{|c|}{$\begin{array}{c}\text { Diameter } \\
\mathrm{mm} \text {. }\end{array}$} & \multicolumn{2}{|c|}{$\begin{array}{c}\text { Volume } \\
\mathrm{mm} .^{8}\end{array}$} \\
\hline & & & & & $\mathbf{L}$ & $\mathbf{R}$ & $\mathbf{L}$ & $\mathbf{R}$ & $\mathrm{L}$ & $\mathrm{R}$ & $\mathbf{L}$ & $\mathbf{R}$ \\
\hline Mar. & $\begin{array}{r}5 \\
12 \\
19 \\
26\end{array}$ & $\begin{array}{r}10 \\
7 \\
7 \\
10\end{array}$ & $\begin{array}{l}70.5 \\
72.5 \\
71.0 \\
66.3\end{array}$ & $\begin{array}{l}25.9 \\
34.0 \\
26.0 \\
22.4\end{array}$ & $\begin{array}{l}26.4 \\
45.8 \\
42.1 \\
19.5\end{array}$ & $\begin{array}{l}26.8 \\
42.6 \\
30.9 \\
20.2\end{array}$ & $\begin{array}{r}10.8 \\
11.1 \\
12.3 \\
8.3\end{array}$ & $\begin{array}{r}10.8 \\
10.9 \\
9.9 \\
8.8\end{array}$ & $\begin{array}{l}2.3 \\
2.6 \\
2.5 \\
2.1\end{array}$ & $\begin{array}{l}2.3 \\
2.9 \\
2.5 \\
2.1\end{array}$ & $\begin{array}{l}52.3 \\
65.1 \\
62.8 \\
27.8\end{array}$ & $\begin{array}{l}51.6 \\
75.3 \\
47.4 \\
30.0\end{array}$ \\
\hline Apr. & $\begin{array}{r}2 \\
10 \\
16 \\
23 \\
30\end{array}$ & $\begin{array}{l}9 \\
8 \\
9 \\
8 \\
5\end{array}$ & $\begin{array}{l}72.1 \\
68.3 \\
71.7 \\
68.5 \\
70.2\end{array}$ & $\begin{array}{l}30.3 \\
27.4 \\
28.5 \\
24.4 \\
23.8\end{array}$ & $\begin{array}{l}32.1 \\
30.3 \\
39.8 \\
30.3 \\
32.6\end{array}$ & $\begin{array}{l}34.1 \\
32.9 \\
40.3 \\
35.7 \\
31.8\end{array}$ & $\begin{array}{l}10.7 \\
10.4 \\
12.0 \\
10.5 \\
10.9\end{array}$ & $\begin{array}{l}10.6 \\
11.2 \\
11.4 \\
11.1 \\
10.8\end{array}$ & $\begin{array}{l}2.6 \\
2.4 \\
2.5 \\
2.2 \\
2.5\end{array}$ & $\begin{array}{l}2.7 \\
2.6 \\
2.6 \\
2.6 \\
2.3\end{array}$ & $\begin{array}{l}59.9 \\
48.8 \\
63.6 \\
39.4 \\
59.6\end{array}$ & $\begin{array}{l}69.9 \\
56.7 \\
64.1 \\
56.0 \\
47.0\end{array}$ \\
\hline May & $\begin{array}{r}7 \\
14 \\
21 \\
28\end{array}$ & $\begin{array}{r}5 \\
11 \\
5 \\
7\end{array}$ & $\begin{array}{l}68.3 \\
66.0 \\
72.2 \\
69.3\end{array}$ & $\begin{array}{l}23.0 \\
22.2 \\
35.0 \\
28.0\end{array}$ & $\begin{array}{l}29.8 \\
25.1 \\
37.6 \\
31.3\end{array}$ & $\begin{array}{l}29.7 \\
25.0 \\
34.2 \\
35.0\end{array}$ & $\begin{array}{l}10.8 \\
10.2 \\
11.7 \\
11.5\end{array}$ & $\begin{array}{r}10.5 \\
9.6 \\
11.9 \\
12.2\end{array}$ & $\begin{array}{l}1.9 \\
2.0 \\
2.3 \\
2.3\end{array}$ & $\begin{array}{l}2.1 \\
2.1 \\
2.3 \\
2.4\end{array}$ & $\begin{array}{l}36.7 \\
34.0 \\
59.1 \\
50.8\end{array}$ & $\begin{array}{l}45.5 \\
36.0 \\
62.5 \\
58.4\end{array}$ \\
\hline June & $\begin{array}{r}4 \\
18 \\
25\end{array}$ & $\begin{array}{l}7 \\
8 \\
4\end{array}$ & $\begin{array}{l}66.3 \\
70.1 \\
68.7\end{array}$ & $\begin{array}{l}20.5 \\
38.7 \\
26.3\end{array}$ & $\begin{array}{l}25.1 \\
34.7 \\
20.1\end{array}$ & $\begin{array}{l}25.7 \\
37.6 \\
21.9\end{array}$ & $\begin{array}{r}9.9 \\
11.4 \\
11.0\end{array}$ & $\begin{array}{l}11.2 \\
12.8 \\
10.7\end{array}$ & $\begin{array}{l}2.3 \\
2.2 \\
1.9\end{array}$ & $\begin{array}{l}2.5 \\
2.4 \\
2.1\end{array}$ & $\begin{array}{l}43.6 \\
51.4 \\
34.7\end{array}$ & $\begin{array}{l}55.9 \\
68.2 \\
38.5\end{array}$ \\
\hline July & $\begin{array}{l}2 \\
9\end{array}$ & $\begin{array}{l}7 \\
4\end{array}$ & $\begin{array}{l}74.1 \\
70.2\end{array}$ & $\begin{array}{l}33.5 \\
31.7\end{array}$ & $\begin{array}{l}37.4 \\
25.9\end{array}$ & $\begin{array}{l}37.0 \\
29.1\end{array}$ & $\begin{array}{l}11.8 \\
10.0\end{array}$ & $\begin{array}{l}11.9 \\
10.9\end{array}$ & $\begin{array}{l}2.3 \\
2.3\end{array}$ & $\begin{array}{l}2.6 \\
2.3\end{array}$ & $\begin{array}{l}55.6 \\
43.8\end{array}$ & $\begin{array}{l}61.5 \\
48.2\end{array}$ \\
\hline
\end{tabular}

No difference was found between the testes of the males collected on land and those collected in water. In both instances the tubules were in all stages of development.

Immature ova were found embedded in the testicular tissue of $10 \%$ of the testes examined microscopically. There were five hermaphrodites in the collection, in which the ovaries were immature and the testes normal. They all showed typical male secondary characters.

The secondary sex characters were always present in mature males. Although they are known to show seasonal variation in other parts of the range of this species, they are retained throughout the year on Java (Church, 1959). Only the first two fingers were found to be pigmented in mature animals. This finding is in keeping with the observations of Stejneger (1907), Boulenger (1912), Van Kampen (1923) and Pope (1931). Liu (1936), however, has reported the presence of well-developed black nuptial pads on the first three fingers of breeding melanostictus in China. All males also showed the characteristic red pigmentation under the chin throughout the year.

The vocal sac, which is median and internal in this species, was also pigmented. The vocal slits opening into it varied in number and position. Of 255 animals examined, 12 had two openings equally developed; 124 had only the left; 111 had only the right; and 8 had no slit at all. But studies of other Javanese populations (Church, 1959), and of China (Liu, 1936), show this to be a highly variable structure in this species.

In keeping with the observations of Davis (1936) for Bufo in general, and Rau \& Gatenby (1923) for melanostictus, Bidder's organ was found in all male animals examined. No seasonal variation in the size of this organ was noted.

The fat bodies were absent or small and undeveloped as in the females.

\section{Discussion}

That Bufo melanostictus can reproduce throughout the year in West Java has been demonstrated by this study. Whether the annual reproductive pattern as reported here for 195758 is typical of every year is still open to question. The chances are that, considered in detail, it is not. Mating in this species appears to be due to fortuities which are determined to a large extent by local and immediate amounts of rainfall. Since in any given month there can be a wide deviation either above or below the monthly rainfall average, these shifts conceivably could bring about yearly variation. September and October, 1957, as illustration, showed rainfall averages far below the normal means for 
these months. For fifty days preceding the "rainy" season almost no rain was recorded in Djakarta. This extended dry interval could have hindered a large number of females from mating during those two months, forcing them to wait until favorable conditions arrived with the northwest monsoon in November. Perhaps in a year of more normal rainfall, the ovarian weights and the number of ovulating females, which were highest at this time, would appear more constant.

A number of other species are also known to depend upon heavy rainfall to bring about breeding, but the causes for this are not altogether clear (Annandale, 1903; Savage, 1935; Berk, 1938; Alexander, 1932; Kirtisinghe, 1957). It is possible, as pointed out by Holmes (1927), that during warm dry weather the body temperature of a toad would be lowered and activity thereby diminished by rapid evaporation of body fluids. During an extended period of drought as much as $50 \%$ of the body might be lost in this way without causing death. The onset of rain would, by raising the body temperature and increasing metabolism, be expected to stimulate activity.

It is questionable whether heavy rains cause Javanese $B$. melanostictus to seek water primarily to breed. The nature of the climate is such that even a few days without rain can bring about unsatisfactorily dry conditions for a toad, and rainfall might only stimulate them to migrate to water to replenish their depleted body fluids. This possibility is pointed up by the fact that both breeding and non-breeding toads enter the water after a rain. Male and female toads deprived of water and kept under dry conditions in the laboratory for as short a time as three days invariably, when given a dish of water, went directly to it and sat in it for some hours. After a few days with lessened rainfall a similar need to replenish depleted body fluids may occur in nature. It is estimated (Schmidt \& Ferguson, 1952) that during a month in which the amount of rainfall in Indonesia drops below 2 inches, evaporation withdraws more water from the soil than is provided by precipitation. These periods, especially if extended, would undoubtedly have desiccating effects on toads, but in spite of this one heavy rain would be enough to bring them out to replenish their body fluids in the newly flooded pools and ditches.

The urge to relieve partial desiccation may be strongly compelling. In a small pool enclosed with a three-foot wire fence close to the laboratory, toads were observed on a number of occasions climbing the fence to enter the pool during a rain. Not all of them were in breeding condition, although eggs were frequently found in the pool after the migration. It would appear that, having entered the water primarily to regain their water balance, mating occurred secondarily. At any given time some female toads are ready to mate, and the testicular findings show that there is always a majority of males available in suitable condition to mate with them. That they can hold back from mating throughout dry weather without ill effect indicates that the process is flexible and not governed by immediate necessity. The longer the dry period prevailed to keep the animals on land, the greater would be the number ready to mate when a rain finally came.

Mating, when it does occur, apparently proceeds indiscriminately. Males have been found in amplexus with females with immature ovaries, and at other times they have been found on land clasping unripe females which presumably have just lett the water. During the time males and females are in the water together, some males may be stimulated by the presence of a gravid female to clasp any female available and to discharge some of their sperm. It is commonly known that frequently many male urodeles as well as anurans will clasp the same female, and male Rana fusca that were unsuccessful in finding a mate have been observed climbing over and through egg masses and discharging sperm over them, apparently stimulated to do so by the egg masses themselves (Holmes, 1934). If male melanostictus were similarly induced to discharge their sperm, either by the presence of a gravid female or by newly-laid eggs, it would account for the large percentage of testes examined which were partially evacuated. On the other hand, one would expect the testes of males after normal amplexus to be emptied of sperm. The testes of a group of males, examined after amplexus and successful spawning of the females in the laboratory, contained tubules which were almost completely devoid of spermatozoa (Plate I, D).

No ready explanation can be found to account for the increased number of females ovulating or ready to ovulate collected during the time of the full moon. Lunar periodicity is of course well-known among the invertebrates, and recently Harrison $(1952,1954)$ has postulated a "moonlight effect" to explain the more frequent occurrence of conception in four species of Malayan rat at some part of the lunar month than at another. In other vertebrate forms, of all the external stimuli known to exert an influence on reproductive cycles, light and photoperiodism have been demonstrated to be most 
definitely influential (Rowan, 1938) and it may be the increase in light at the time of the full moon which is working here.

Parker (1903), Torrelle (1903) and Pearse (1910) have shown frogs and toads to be sensitive to light intensity and color even when blinded, their forebrains removed and their optic nerves cut; and March (1937a, b) has demonstrated with experimental irradiation that light may play an important part in regulating the breeding cycle in various temperate zone Amphibia. Church (unpublished) has found evidence that Rana cancrivora is perhaps also influenced in its reproductive behavior by the lunar cycle, although in this case by a negative phototropism; and data collected by Church (unpublished) in Bali on B. biporcatus indicate that this species, like melanostictus, is also more active in its breeding habits during the time of the full moon.

It appears possible that the increased light at the time of the full moon, which is considerable in the tropics, might be at least partially responsible for bringing about an increase in breeding activity in $B$. melanostictus, but further investigation of the problem is needed before definite conclusions can be drawn.

\section{SUMMARY}

1. Under the constant climatic conditions of West Java, Bufo melanostictus Schneider is able to reproduce throughout the year. The variation from year to year in monthly rainfall, however, probably causes local and immediate shifts in the reproductive pattern.

2 . Within the yearly cycle which is determined by rainfall, there is also a monthly rhythm in ovulation which follows the lunar cycle. More females which were ready to ovulate or had just ovulated were found during the time of the full moon; in the males there appear to be individual sex cycles, uncorrelated with the annual or lunar cycles.

3. In many cases mating may occur secondarily after the animals have migrated to water after a dry period to replenish body fluids.

4. The contents of the stomach show that there is an unending food supply available throughout the year.

5. The fat bodies are insignificant in size in both males and females.

6 . There is no inactive period of hibernation for either males or females.

7. In the females the ovaries can equal $30 \%$ of the gross body weight; there is no significant difference between the weights of the two ovaries; three generations of eggs can be found in a mature ovary; and the size of the oviducts increases as the oldest generation of ovarian eggs matures.

8. In the males the average absolute weight of the testes is $0.2 \%$ of the body weight; there is no significant difference between the weights and dimensions of the two testes; sperm in all stages of development can be found in some testicular tubules at all times; the first two fingers bear black nuptial pads throughout the year and the redness under the chin is also retained permanently; Bidder's organ was present in all males examined; and there was a variation in the number and position of vocal slits.

\section{REFERENCES}

Alexander, G.

1932. Bidder's organ in Bufo melanostictus Schneider. Copeia, 78.

1933. Secondary sexual characters of Bufo melanostictus Schneider. Copeia, 204.

Allende, I. L. C. DE

1939. Cycle sexuel du crapaud Bufo arenarum femelle. C. R. Soc. Biol., Paris, 130:676.

AnNandale, N.

1903. Fasciculi Malayenses. Liverpool.

BERK, $\mathbf{L}$.

1938. Studies in the reproduction of Xenopus laevis. I. The relation of external environmental factors to the sexual cycle. S. Afr. J. Med. Sci., 3:72.

BOULENGER, G. A.

1912. A Vertebrate Fauna of the Malay Peninsula. London.

CHURCH, G.

1958. A preliminary report of the reproductive cycle of the Javanese toad, Bufo melanostictus Schneider.

I. Ovulation in Bufo melanostictus.

II. (With The Djin Tek.) Cyclic changes in the testes of Bufo melanostictus.

III. (With Sie Kian Tjong.) Glycogen concentration in the liver of Bufo melanostictus in relation to the maturity of the ovaries.

IV. (With J. A. Kusin \& Tio Kian Ling.) Cyclic changes in the hemoglobin concentration and the number of erythrocytes in Bufo melanostictus.

V. (With Gusti Mohammad Hussaini.) The volume of the hypophysis in relation to the maturity of ovarian eggs in Bufo melanostictus. Council for Sciences, Djakarta, Indonesia.

1959. Size variation in Bufo melanostictus Schneider from Java and Bali. Treubia, 25:1. 
1960. The invasion of Bali by Bufo melanostictus Schneider. Herpetologica, 16:1.

Davis, D. D.

1936. The distribution of Bidder's organ in Bufonidae. Field Mus. of Nat. Hist., 20:15:

HARRISON, J. L.

1952. Breeding rhythms of Selangor rodents. Bull. Raffles Mus., 24:109-131.

1954. The moonlight effect on rat breeding. Bull. Raffles Mus., 25:166-170.

Holmes, S. J.

1934. The Biology of the Frog. New York.

KAMPEN, P. H. VAN

1923. The Amphibia of the Indo-Australian Archipelago. Leiden.

Kirtisinghe, $\mathbf{P}$.

1957. The Amphibia of Ceylon. Colombo.

LIU, C. C.

1936. Secondary sex characters in Chinese frogs and toads. Field Mus. Nat. Hist., Zool. Ser., 22:115.

\section{March, F.}

1937a. Relative growth in Amphibia. Proc. Zool. Soc. London, 108:415.

1937b. Some hormone effects in Amphibia. Proc. Zool. Soc. London, 107:603.

\section{PARKER, G. H.}

1903. The skin and eyes as receptive organs in the reactions of the frog to light. Am. Jour. Phys., 10.
PeARSE, A. S.

1910. The reactions of amphibians to light. Proc. Am. Acad. Arts Sci., 45:161.

PoPe, C. H.

1931. Notes on amphibians from Fukien, Hainan and other parts of China. Bull. Amer. Mus. Nat. Hist., 61:397.

Rau, A. S., \& J. B. Gatenby

1923. Notes on the distribution, morphology and cytology of the organ of Bidder. J. R. Micro. Soc., 19.

ROWAN, W.

1938. Light and reproductive cycles. Biol. Rev., $13: 374$.

Savage, R. M.

1935. The influence of external factors on the spawning date and migration of the common frog, Rana temporaria temporaria Linn. Proc. Zool. Soc. London, 105:49.

SCHMidT, F. H., \& J. H. A. Ferguson

1952. Rainfall types based on wet and dry period ratios for Indonesia with Western New Guinea. Kementerian Perhubungan Djawatan Meteorologi dan Geofisik. Djakarta.

\section{STEJNEGER, $\mathbf{L}$.}

1907. Herpetology of Japan and adjacent territory. Bull. U. S. Nat. Mus., 58:577.

TORELLE, E.

1903. The response of the frog to light. Am. Jour. Phys., 9.

\section{EXPLANATION OF THE PLATE}

\section{Plate I}

A. Mature tubule with spermatozoa still attached

to Sertoli cells (app. 250X).

B. Testis in which spermatozoa are free in the

tubular lumina. (app. 75X).

C. Recently evacuated testis (app. 75X).

D. Testis immediately after amplexus (app. 75X). 

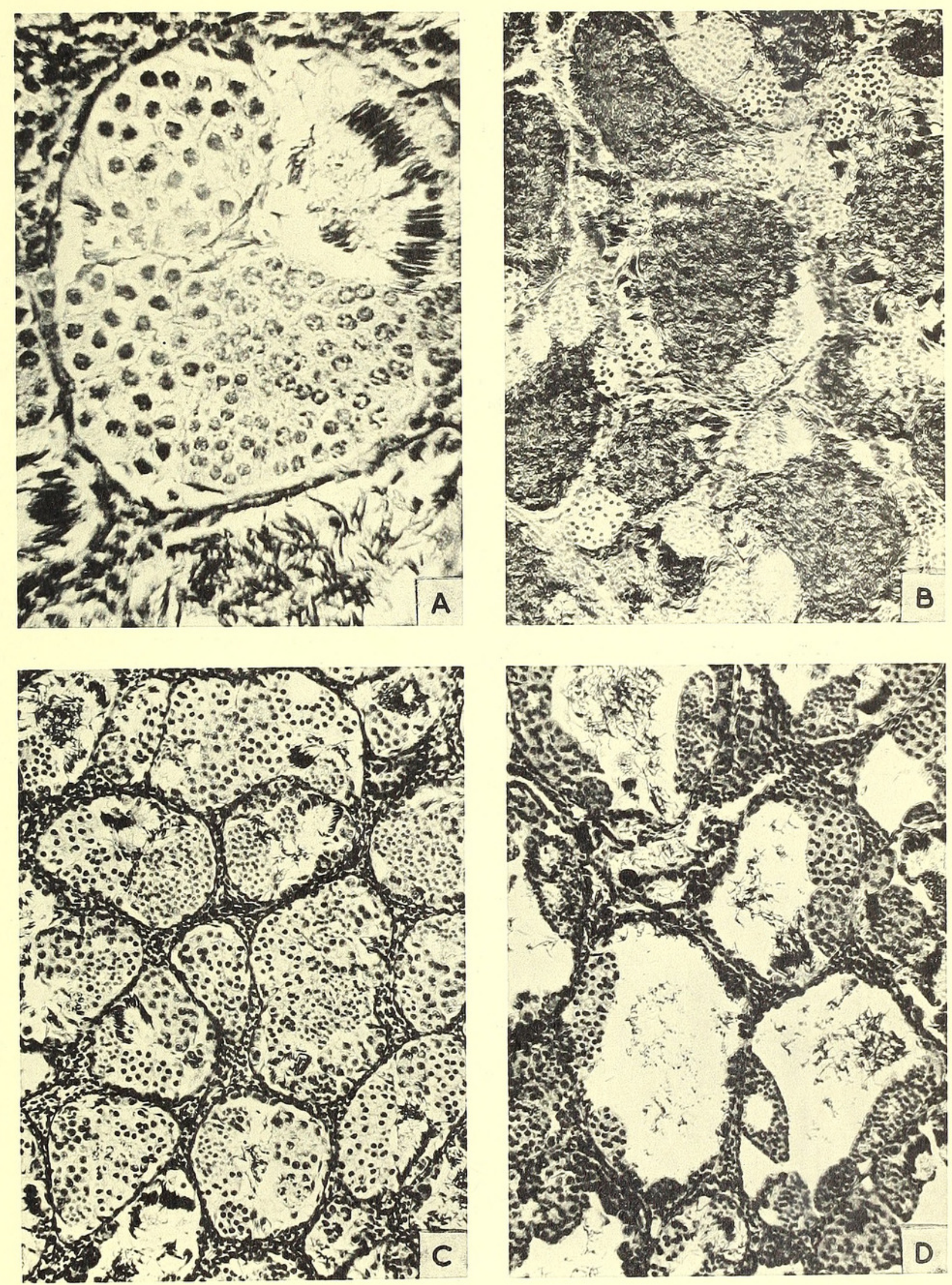

ANNUAL AND LUNAR PERIODICITY IN THE SEXUAL CYCLE OF THE JAVANESE TOAD, BUFO NELANOSTICTUS SCHNEIDER 


\section{$2 \mathrm{BHL}$ Biodiversity Heritage Library}

Church, Gilbert. 1960. "Annual and lunar periodicity in the sexual cycle of the Javanese toad, Bufo melanostictus Schneider." Zoologica : scientific contributions of the New York Zoological Society 45(13), 181-188. https://doi.org/10.5962/p.203361.

View This Item Online: https://www.biodiversitylibrary.org/item/208290

DOI: https://doi.org/10.5962/p.203361

Permalink: https://www.biodiversitylibrary.org/partpdf/203361

\section{Holding Institution}

Smithsonian Libraries

\section{Sponsored by}

Biodiversity Heritage Library

\section{Copyright \& Reuse}

Copyright Status: In copyright. Digitized with the permission of the rights holder.

Rights Holder: Wildlife Conservation Society

This document was created from content at the Biodiversity Heritage Library, the world's largest open access digital library for biodiversity literature and archives. Visit BHL at https://www.biodiversitylibrary.org. 